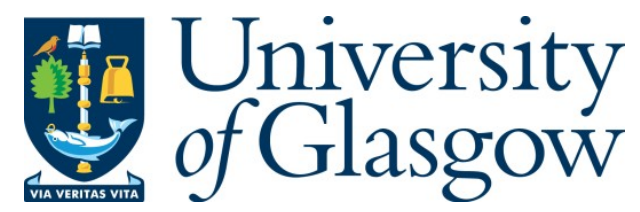

Lundie, D., and Conroy, J. (2015) 'Respect Study’ the treatment of religious difference and otherness: an ethnographic investigation in UK schools. Journal of Intercultural Studies, 36(3), pp. 274-290.

Copyright () 2015 The Authors

http://eprints.gla.ac.uk/98481/

Deposited on: 13 May 2015

Enlighten - Research publications by members of the University of Glasgow http://eprints.gla.ac.uk 


\section{'Respect Study' the Treatment of Religious Difference and Otherness: An Ethnographic Investigation in UK Schools}

\section{David Lundie \& James Conroy}

Understanding and appreciating the beliefs and practices of others feature prominently among the aims and purposes of Religious Education in UK schools. Drawing on ethnographic data from the 'Does RE Work?' project, this paper presents two conceptions of 'in/entoleration' a deliberate process of inculcating tolerance in pedagogy. Entoleration, akin to enculturation, encourages sympathetic and transformative encounter with others' beliefs. Intoleration, akin to indoctrination, risks eliding both difference and encounter in the service of a predetermined aim of nurturing uncritical tolerance. The former is categorised by pedagogies of encounter with the other as person, while the latter often focuses on externals and strangeness.

Keywords: Religious Education; Intercultural Education; Pedagogy; Encounter; Other; Stranger

\section{Introduction}

In my RE lessons, I have learnt to become more broadminded, to accept other people's beliefs and faiths and not to let race or religion come in the way of what you see in an individual. (QCA 2004: 6)

\footnotetext{
David Lundie is Lecturer in Philosophy of Education at Liverpool Hope University. His research interests include religious and moral education, digital ethics and educational ethnography. His doctoral research focused on understandings of Otherness and moral development among secondary school students in areas of community fragmentation in London and Northern Ireland, as part of the 'Does RE Work?' project. Correspondence to: David Lundie, Philosophy of Education, Liverpool Hope University, Hope Park, Taggart Avenue, Liverpool L16 9JD, UK. Email: lundied@hope.ac.uk; James Conroy is Vice Principal for Internationalisation at the University of Glasgow and a Fellow of the Academy of Social Sciences, Glasgow G12 8QQ, UK. His research interests include religious and moral education, and philosophy of education. He was Principal Investigator on the 'Does RE Work?' project, which sought to trace aims, policies and practices in Religious Education in secondary schools across the UK.
} medium, provided the original work is properly cited. 
An understanding of, as well as appreciation for, the beliefs of others features prominently among the multifarious aims advanced in political and pedagogic pronouncements on Religious Education (RE) in UK schools. The above statement, a carefully selected example of student feedback, sets out a conception of 'learning about religions', one of the principal attainment targets for the subject in England and Wales (QCA 2004: 8); a concept rendered still more disquieting in the (now superseded) 5-14 guidance for Scotland, which enumerates 'other world religions' alongside Christianity and personal search as constitutive of the subject (SOED 1992: 4). This foregrounding of Otherness begs important questions regarding the role of state multiculturalism; the relation of learning about religions to the cultivation of values and dispositions; the epistemic claims about truth and plurality; and interculturalism in UK RE pedagogy. Understanding the religious and cultural Other is constitutive of the contested and often contradictory expectations of intercultural education, mediated primarily through RE. This aim emerges in particular historical circumstances to defend and explain the continued mandatory presence of religion at all levels of public schooling yet is freighted in a country with demographically declining levels of religious affiliation and practice.

Religious pluralism is formative of RE in England and Northern Ireland. Nonconformist Protestant churches played a significant role in the historical development of universal education in the nineteenth century, necessitating the Cowper-Temple clause of the 1870 Foster Education Act, which stipulated that collective worship and religious instruction would be provided in the common school, but that this was not to follow the catechism or formulary of any denominational church. The unique sociology of English RE as at once committed and lacking an object of commitment continued into the twentieth century, anxious to reflect demographic changes in a post-colonial age by 'taking account of the teaching and practices of the other principal religions represented in Great Britain' (Education Reform Act 1988 8.3).

Recently, the focus has been on 'tolerance', as a conservative articulation of the intended learning outcome of RE. Of late inspections and moral panics (Lundie 2014) around alleged segregated religious monocultures in British schools have led the Cameron Government to propound the 'tolerance of others' as one of five core 'British values' to be promoted in all schools (see, Cameron 2014). This paper argues that in classroom practice certain conceptual disjunctions commonly arise, precipitating a disconnect between students' understanding of the religious beliefs and practices of others and their dispositions towards adherents of that religion. Here we advance the concept of in/entoleration: a deliberate process of inculcating tolerance through the curriculum. This concept is capable of a transformative reading, whereby entoleration - akin to enculturation - encourages sympathetic discernment of the merit in Others' beliefs and practices. Entoleration is an entering into the lived experience of the Other, without being subsumed by it. Subtly distinct from this, a prescriptive reading of intoleration - akin to indoctrination - is also present in RE practice, which risks eliding both discernment and difference in the service of a predetermined aim of nurturing uncritical tolerance. While the former 
brokers an encounter with the other as person, the latter focuses on externals and strangeness. Intolerance needs to be considered alongside intoleration, as an expression of narrow and restrictive 'tolerance', precluding intercultural encounter. This latter conception is problematic for both ethical and pragmatic reasons. In what follows, examples of both conceptions in classroom practice are presented, and the epistemic assumptions that underpin them are explored.

\section{The Other in Curriculum and Policy}

The Schools Council Working Paper 36 (1971: 16) recommended that the learning of (Christian) religion in schools was no longer appropriate to the diverse, secular nature of British society. This claim precipitated dramatic changes in RE. In response, Michael Grimmitt (1987) argued that while 'learning religion', understood in Christian catechetical terms, had no place in the common school, two aims of 'learning about' and 'learning from' religions remained meaningful and appropriate for a post-confessional RE. Learning about religions, understood as a theological or sociological study of the faith traditions represented in the UK, was later to form the basis of SCAA Model Syllabus 1 (1994) Living Faiths Today. Central to the Model Syllabus 2 (1994), Questions and Teachings, was the idea of learning from religion: understood as a process of personal reflection on the teachings of major religious traditions as they relate to existential questions. This distinction and the language of 'learning about' and 'learning from' are preserved in the two attainment targets for England and also reflected in the separation of Christianity, world religions and 'personal search' in Scotland's 'Curriculum for Excellence'. These two core aims having displaced a confessional model of RE, a further plurality of aims have proliferated, including:

[developing] an individual's knowledge and understanding of the religions and beliefs which form part of contemporary society;

[provoking] challenging questions about the ultimate meaning and purpose of life, beliefs about God, the self and the nature of reality, issues of right and wrong, and what it means to be human $[\ldots]$;

[developing] pupils' knowledge and understanding of Christianity, of other principal religions, other religious traditions and worldviews that offer answers to questions such as these;

Contribute to pupils' personal development and wellbeing and to community cohesion by promoting mutual respect and tolerance in a diverse society

[making] important contributions to other parts of the school curriculum, such as citizenship, personal, social, health and economic education [...];

[offering] opportunities for personal reflection and spiritual development, deepening the understanding of the significance of religion in the lives of others individually, communally and cross-culturally. (DCSF 2010: 2)

The relation between the promotion of 'mutual respect and tolerance' and reflection on ethical questions, and the answers posed by religious and spiritual traditions is not unproblematic, but this largely passes without comment in policy and curriculum literature. Although more recent critiques of phenomenological RE have centred on 
their misrepresentation of concepts of holiness (Gearon 2013: 141) or to a reductive sense of the transparency of the Other in the service of dialogue (Strhan 2010: 27), such critical voices have yet to make significant headway in teacher education and professional practice. While in many ways this post-confessional model aims at the cultivation of the kind of shared 'basic values' that underpin civic approaches to intercultural education (Gundara 2000: 80), such values remain at the political level and are arguably inappropriate to a religious education.

Education policy, requiring as it does a degree of stability and commonality, struggles to incorporate approaches to encounter with Otherness and the stranger, which are necessarily disruptive and 'made of change' (Alred and Byram 2003: 5). These encounters are no longer isolated but occur frequently in interfaith contexts (Keaten and Soukup 2009: 168), constituting what Turner (1974: 250) terms a liminal crisis, in which a consensus no longer exists around key values or the means for arriving at agreement around these. While it may be expected that an interfaith paradigm, such as described above, would, in an increasingly plural society, immerse itself in the complexities described in the extensive literature on Otherness and the stranger (see, for example, Hoffman 1983, Smith 1996, Moran 2001), the necessary curricular stability of the classroom environment, as we shall go on to see, limits these encounters in practice. As the intention of this paper is to extrapolate models from practice, it would be disingenuous here to engage in a tangential exploration of this often posited, but rarely enacted, transformative encounter.

This separation of certain social aims from the personal-reflective dimension of religion, in turn separated from its cognitive or doctrinal content, has been criticised by Felderhof (2007: 91) on the grounds that any attempt to communicate the 'truths of religious life must make a claim on the emotions and commitments of the learner'. Challenging Grimmitt's thesis of post-confessional RE, Andrew Wright contends that:

[e]ffective spiritual education [...] must be equally committed to education as nurture and education as critique [and] that indoctrination is both a necessary and inevitable component of effective spiritual education. (2000: 113)

At its most simplified, teaching religion can be transformed into a pedagogic and rhetorical device for securing certain behavioural and attitudinal goals on behalf of society, a kind of 'civic religion', which would shift the purpose of RE from the doctrinal beliefs and lived experiences of religions to a resource for the cultivation or modification of given dispositions and behaviours. This distinction between propositional and dispositional learning is central to the argument for an effective intercultural education, which has to rest on authentic claims about the lived experience of the Other, not an uncritical attitude of indifference to Otherness.

Shorn of critical depth, RE may function as indoctrinatory. The charge that RE is indoctrinatory often carries with it the implicit assumption that indoctrination works only in favour of religious belief. The presumption that a secular model of education is value-neutral is problematic in multi-faith $\mathrm{RE}$, because it leaves unanswered important questions as to the epistemic grounding of the study of religion. Neither 
an attempt to lay this groundwork within a faith tradition nor within a critical sociology of religions necessarily entails or necessarily excludes indoctrination understood as an attempt to 'bypass the reason' (Rose 1996: 175) or to teach with the intention of inculcating belief regardless of the evidence (Copley 2005: 4). As we have argued elsewhere (Conroy et al. 2012: 319), a RE confined to comparative descriptions of the social phenomena and practices of religions (learning about religions), detached as it is from religion as a way of deriving meaning from one's being in the world, brokers an attenuated understanding of religion.

Since the development of the SCAA syllabi in the 1990s, a range of initiatives have attempted to reconcile the cognitive and affective dimensions of $\mathrm{RE}$ in a plural context. These attempts are themselves nested within a unique structure, exempt from National Curriculum (NC) determinations, yet with 'non-statutory' national guidance for England closely mirroring NC structure, down to the typesetting and style of curriculum handbooks (DCSF 2010). The guidance itself, while drawing upon intercultural approaches to dialogical RE in its theoretical underpinning (see, for example, Ipgrave 2011), is fundamentally 'an "English compromise", pragmatic, written by [...] officials [...] clear but flexible and inclusive with a set of values whose origins are unclear' (Emerson-Moering 2007: 11).

Guidance passes through a layer of local determination, the Standing Advisory Councils on Religious Education, which by law must include 'the principal nonChristian religions represented in the area' (Lundie 2012: 26). The national guidance recommends a 'key concepts' approach as a way of integrating the two attainment targets. Yet the extent to which these targets have created an entrenched two-track $\mathrm{RE}$ in many professionals' minds is illustrated by guidance for Church of England schools, which suggests that the first three key concepts are 'predominantly learning about religion', while the latter three are 'predominantly learning from religion' (National Society for Promoting Religious Education n.d.: 12-3). Such confusions and variations are echoed in other parts of the UK and stem from a diffuse and decentred curriculum development process. In this inattention to, or pragmatic elision of, foundational values, a range of aims and practices emerge in which teachers attempt to combine an affective commitment to mutual understanding and pluralism with learning about the religious beliefs and practices of Others.

\section{Methodology}

In attempting to uncover the implicit values of multi-faith RE as enacted by UK teachers, this paper draws on an extensive ethnographic data-set gathered during the 'Does RE Work?' project. The project sought to explore the enactment of RE policy and the criteria used to judge effectiveness in a range of contexts across the UK. This included all three legal jurisdictions (Scotland, Northern Ireland, England and Wales), schools in areas of inter-community tension and schools of a religious character (Lundie 2010: 168). In-depth ethnographic studies were carried out, focusing on the shape of teachers' and students' beliefs and intentions. 
A team of five ethnographers worked in 24 schools across the UK during 20082010. As the project sought to unearth contestations in aims and practices, and to explore the possibility of effective RE, purposive sampling was employed, with schools self-selecting as exemplars of good practice in RE. Mindful of the importance placed on Other religions, the sample included schools in the largest multicultural cities in each of the three jurisdictions: London, Glasgow and Belfast. This purposive sampling took the researchers into a diverse range of provision: including schools struggling to maintain a diverse intake amid racial tensions in areas of urban deprivation; an integrated school educating Protestant and Catholic children together in Northern Ireland; a Muslim-majority school actively engaged with the government's community cohesion agenda; Catholic and Anglican faith schools trying to live out their mission and values in inclusive settings; selective grammar schools engaged in framing RE as an intellectually rigorous discipline; and suburban schools struggling to frame the relevance of $\mathrm{RE}$ for young people immersed in a thoroughgoing secularity.

A coding model was developed from initial discussions with policy-makers (Baumfield et al. 2011: 14). This model included questions around the nature of conversation, whether language presupposes consent or permits space for disagreement, whether students are able to engage in self-narration, the use and treatment of religious texts and symbols, and engagement with boundaries between religious ideas and categories. If RE is to be concerned with more than descriptions of belief and practice, it needs to engage with questions of meaning, mystery, symbolic order and representation (Conroy et al. 2012: 312-14), so the ethnography sought thick description of the extent to which classroom discourse engaged such concepts. From a series of coding comparisons and meetings between field ethnographers, as well as a reflexive performance of vignettes from the data to an audience of school pupils (Lundie and Conroy 2012: 333), a set of ten themes were distilled, among which four are of direct relevance to this paper:

- The fit between teacher, pupil and school values in the RE curriculum

- The language and treatment of immanence and transcendence, touching on pupils' levels of religious experience and religious literacy

- The role and approach to multicultural awareness in the RE classroom

- The epistemic claims made about truth and plurality in the RE classroom. (Conroy et al. 2013)

Drawing upon anthropological, philosophical and theological resources and expertise to interrogate $\mathrm{RE}$ as a social practice, the ethnographic approach recommends itself because it seeks to understand the individual 'as necessarily where they are' (Trondman 2008: 129), highlighting situations where voices are conspicuous by their absence (Battaglia 1997) or have been silenced or distorted (Behar and Gordon 1995: 13). 
Ethnographic methods can be useful for critical pragmatism in cases where local understanding has become problematic - perhaps as a result of intercultural static or changing conditions (Feinberg 2014: 2).

The ethnographic approach used in the 'Does RE Work?' project draws upon the critical tradition, concerned with the ways in which culture reproduces social processes through cultural commodities such as textbooks, learning environments and film (Carspecken 2001). The reproduction of discourses of 'Otherness' and 'tolerance' and the presumed positionality from which these Others are defined was a particular focus in analysing data gathered from classroom observation, focus groups, analysis of 'found texts' - such as student workbooks and lesson plans - and multimodal resources such as wall displays and the materiality of the RE classroom. The researchers were aware of the need to attend to the ordinary lived experience of the teaching and learning of RE in diverse contexts. The ethnographic approach focuses on experiential meaning in the 'life world', the locus of interaction between objects, experience and perception.

To gain an understanding of the impact of the cumulative practice of RE in the primary and secondary sectors, the ethnography focused on Year 10/11 students in Northern Ireland and England (S3/S4 in Scotland, aged 14-16). This coincides with preparation for the first sets of high stakes examinations (GCSE's in England and Northern Ireland, Standard Grades in Scotland). In this context, the imperative of examination success tended to elide other meanings and purposes from RE in all but the most determined and purposive of pedagogies. In most of the schools in which fieldwork was carried out, RE was taught in one or two 45-50 min periods per week. Even where students were studying for a qualification of equal weighting to other GCSE/Standard Grade subjects, this was often delivered in around half the time allocated to comparable subjects in the humanities and social sciences.

All ethnographic sources were uploaded to a single database in NVivo 10. Sources included ethnographers' field notes, transcripts of focus groups and interviews with teachers, students and school leaders, photographs, scanned copies of student workbooks and teacher lesson plans, audio recordings of classroom interactions and publicly available documents such as school prospectuses and inspection reports. The data-set included over three million words of text, besides audio and visual sources. Data were coded by three of the ethnographers, with a sample blind doublecoded, producing an 85.88 per cent inter-rater reliability (Conroy et al. 2013: 33). The data reported in this paper are drawn from a single query, representing the data coded under 'Student-Teacher Interaction' and any one of the four thematic codes listed above, this generated a sample of 286 references drawn from 18 of the 24 schools, a total of 71,278 words. Having generated this report, references were further coded by interaction patterns to identify closed and open questioning, predetermined aims and aims open to challenge, reflective pedagogies and learning of religious content. From this further stage of coding, the following two conceptual models of learning about others' religious beliefs were refined and developed. 


\section{Entoleration: Pedagogy of Encounter}

The first series of examples from the ethnographic data-set illustrate the concept of 'entoleration', in which students are invited to engage in authentic encounter with the Others about whose beliefs they are learning, in a way which does not presuppose a set of affective outcomes or values. In entoleration, RE functions as a space for encounter, rather than path to consensus.

By way of illustration, in a Muslim-majority school in East London, a field trip to a Hindu Mandir offered students an opportunity to encounter a culture which they had heretofore experienced largely through crude cultural stereotypes. The ethnographer's field notes are worth reproducing at length:

There is very tight security inside the Mandir, no cameras, no bags, the girls seem unphased in the large entrance hall, but the atmosphere change[s] as we are led up into the prayer room. [Four] girls stand and watch a man prostrating himself before a murthi, one turns to the other smiling, but notices that I am watching and holds back on whatever she was about to say to her friend. The girls exhibit fear: they keep their heads down; peer over from as far away as possible to read the signs at each murthi to get the information to complete their workbook; one girl looks scared, hunched over as she walks; a girl clicks her pen repeatedly; two girls hold each other's hands; there is visible fear and discomfort; one girl has her fist in her mouth; one passes a disdainful glance at a man sitting on the floor. The silence in the prayer room seems to increase fear; one girl stares at a woman praying, a few girls laugh and smile, they cluster together, girls lean on each other's shoulders to write $[. .$.

When we go into the museum exhibit, the girls seem much more comfortable, five sit on the floor, leaning against a wall, to write in their workbooks, some get all of their answers from the exhibition guide, and don't walk around the exhibit at all [...]. Three girls stand before a model illustrating a Hindu story, one girl looks puzzled, to which another explains:

'sacrifice' - the story is about self-giving

'that's nice' one girl says, giving an immediate first impression

'no it's not!' the third interjects, passing judgment

'shut up!'

'it's just models' - the first girl belittles the significance of the conflict by pointing back to the materiality of the exhibit.

Another group of girls cluster around a mirror, this changes the nature of the interaction, it becomes more informal, a familiar setting (a bedroom or bathroom), girls chat and catch up [...]

One girl sits cross-legged on the floor in the prayer room, identifying herself by body language with the devotees, suggesting the environment is no longer a threat. I note that something is visibly happening, several pairs have de-coupled, are wandering alone in the space; the girls begin admiring the decoration on the walls, not looking narrowly for information for their workbook task. There are tangible signs of increased comfort and understanding.

In a Year 9 (aged 13-14) class in an Inner London Catholic girls' school, students engage with moral questions around the death penalty: 
The teacher uses quite complex language, the girls seem to understand and respect the discussion. He asks students to write down: 'What do you think the Christian view should be on the death penalty? Explain your view on the death penalty'. The student sitting next to me has written three bullet-point sentences summarising the PowerPoint slide and the teacher's words about the death penalty.

The teacher goes over to talk to a group of four girls about their views. One girl suggests that if someone has been 'yarding' [engaging in gang killings] they should receive the death penalty, but not for one murder [...]

When discussing sanctity of life, pupils draw in killing in self-defence. Their language isn't theoretical, it belongs to 'the streets' (teacher's words), the students' own life experiences: 'shake someone up in a few spots', 'shanking'.

The teacher respects their discussion, but sets clear boundaries 'do not bring the streets into the classroom'.

The lexical moves and shifts within this cache of revealingly autoethnographic personal reflections are thick with the modulation of troubled, if labile, identities. The teacher engages with the pragmatics of a politically and culturally shaped pedagogy in a dangerous space. These approaches to cultural, moral and religious encounter, a culture of openness modelled in classroom and in religious spaces, are held up both by teachers and by our observations as essential to authentic approaches to tolerance in RE. A further example of this approach to teaching can be seen in the following interaction during a Year 10 (aged 14-15) class in another London comprehensive school. Students here explore the problem of evil in preparation for a GCSE examination in philosophy and ethics:

Mr C: 'If God loves me, he wants to stop me dying of cancer, he wants to stop me feeling pain. If God's all powerful, he is capable, he is able to stop me dying from cancer. So what would any logical, reasonable person conclude from the fact that God can stop me but hasn't?'

T: 'That that was how you're meant to die'

Mr C: 'Well, I don't think that's the logical/'

T: 'Well, does you believe in death?'

Mr C: 'Believe in death?'

T: 'Aye'

Mr C: 'I don't know how you/'

T: 'Like you have to die at one point' [...]

Mr C: 'Does everybody have to die?'

S: 'Yes.'

Mr C: 'If God is all powerful, could God not have created a world in which nobody dies?'

T: 'He never done that though, you have to die!' - some girls laugh at the intensity with which $\mathrm{T}$ is entering into this discussion.

S: 'Yeah, but that world's before like heaven and hell, so if this world was perfect, what was the purpose of heaven and hell?'

Mr C: 'That's an interesting question, we're going to come back to that'

J: 'Cos God created the world, but Satan/'

Mr C: 'God loves everybody' [pause] question mark - four students say together, 'yes.' - 'Right, so if God loves everybody, why does he send some people to have sticks poked at them for all eternity, that doesn't sound like/' 
S: 'Cos they done bad' [...]

A: 'I don't know about the Bible, yeah, but in the Qur'an it says, it says yeah that through the hard times you have to, you have to stay patient [S: "Yeah"] and if people die you're not going to go "aw I don't believe in God", and all that, cos that's your problem and you're gonna go to hell for that. And it clearly states, like, bad stuff happens.'

Mr C: 'So essentially what you're saying is that evil is a test of faith?'

S: 'Yes'

A: 'Yes'

S: [to A] 'I like that, you know.'

$\mathrm{S}$ and T's account takes as obvious as Christian anthropology and eschatology, already invested with meaning for their lives. Mr C's questioning proceeds from a philosophical logic, the God who 'could' is juxtaposed with the God of S and T's faith, who made things as 'meant' to be. This enactment opens up a paradoxical space - each side's questions appear strange, even absurd, to the other. Instead of seeking oppositional dichotomies between faiths, this pedagogy of encounter facilitates a discursive space for incommensurable values, without intention of resolution. The theme of articulating and explaining belief often involves the challenging of boundaries between self and other: Christian and Muslim perspectives on theophany mutually reinforce one another in this encounter with a form of reason which presents itself as Other in relation to both.

Pedagogies of encounter involving open questions do not need to presume a neutrality towards values but can also proceed from within a faith perspective. In a Catholic school in Scotland, one teacher remarked in interview:

I think one of the main skills we hope that people will develop is, let's say [...] religious discernment that they will, and that includes the information, the values that we give them, that they will be able to look at things and see things as they really are and allow them to say 'Well, what's going on here, what's this about, what is this value, what is this person about?' and in all honesty they will come to their own conclusions, question, search for the truth because what you get from the discussions $[\ldots]$ they'll state what they think then you ask them to explain why and they can't. So there's no sort of foundation. You try to push them into thinking, to consider why that might be happening $[. .$.$] you try to encourage them to look at it$ [Church teaching] and take responsibility that your life is defined by the values you hold [...]. Give them a bit of savvy almost, they become wiser, a bit of wisdom to be able to make those decisions [...]. It's not just us, but also through the Holy Spirit, and it's not us ourselves exclusively, we teach them that. We give them the opportunities to experience that, to be open to that.

The foregrounding of responsibility, discernment and decision seeks to articulate forms of reasoning, albeit encoded within a religious tradition, which prepare young people to encounter difference from a position of defined identity. Authenticity towards identity formation can enhance this intercultural understanding, even when communicated from within monocultural and faith-based settings (Pike 2010: 188; Conroy et al. 2013: 83). Even within this religiously acculturated professional discourse, modulation and pragmatics, 'savvy', are foregrounded. 
The spaces of encounter enumerated above are also, notably, highly sensitive spaces, often highly charged. The role of the teacher in setting appropriate boundaries to keep the classroom a safe space is often challenged. These challenges are consistent with the notion of 'liminoid' spaces in ethnology (Turner 1988): these are spaces for transformative encounter and the remaking of meaning, often occurring in privileged spaces, in a subjunctive mood and reflexive voice, proceeding from an independent and critical source. Such encounters are profoundly dialogical, requiring an encounter between the propositional content and doctrinal claims of faith and the life world of the learner, and yet antithetical to a predictable synthesis, an uncritical nurture of the disposition of tolerance.

\section{Intoleration: Pedagogy of Tolerance}

The title of this paper comes from an interview with a head of department in a religiously diverse school in London, who commented that:

a lot of our pupils, their home life is very much based around religion and also it's really good because lots of parents will say 'well we understand the importance of my son or daughter's learning of other religions, so that they will respect them'. We did a big thing in Year 7, it used to be RE and you should respect everyone and now it's RS - 'respect study', and respect is the core.

This designation reflects a reductive and essentialising redefinition of RE around the centrality of 'respect' as a meta-narrative into which learning about religions has purpose and rationale for an increasingly secular and disinterested student population. In contrast to the subtleties and discursive liability of the earlier examples, for the most part, extensive commentary on the following examples is not needed. Intolerative pedagogical encounters are linguistically 'flat'; their meaning is exhausted by their description.

Not only is such a reductive model epistemologically problematic - reducing religious values and practices to an instrumental conduit for framing and relating to an estranged Other - but also the empirical observations point to repeated failures of such a reductive pedagogy to cohere with the lived experiences of young people (Lundie and Conroy 2012: 339). Such a focus is reproduced, for example, in a Year 10 (aged 13-14) class on Islam in a Catholic school in Northern Ireland:

Mrs $\mathrm{W}$ asks why the class are studying Islam.

D: Cos it's good to know about other people.

$\mathrm{M}$ : We live in a multicultural society.

$\mathrm{J}$ : We're exposed to more and more cultures.

Mrs W: What does it nurture in us?

M: Respect

Mrs W: It deals with what S? [silence] Stereotyping. If we don't [know] we [stereotype others] 
The litany of rehearsed responses to 'other people' is illustrative of this practice. While the language of 'nurture' is absent even in faith school perspectives, with teachers stressing the need for students to 'come to their own conclusions', the uncritical nurture of respect is seldom problematised. Returning to Grimmitt's formulation, this pedagogy concerns itself neither with learning 'about' the Islamic faith as academically worthwhile, nor with learning 'from' its spiritual tradition, but with learning a series of predefined dispositions from a pre-evaluated form of RE.

Whereas challenging the boundaries between self and Other is characteristic of entoleration, a universalising syncretism that elides the distinction altogether can be noted in several cases of closed pedagogy characteristic of intoleration. In these cases, the Other is not present, and learning from their beliefs is a thinly veiled appropriation of the Other's dispositions towards their religion to augment one's own. In the same lesson quoted above, the teacher concludes by asking her class about the difference between Muslims' use of the Qur'an and Catholics' use of the Bible:

Do we use it as reverently?

No.

So perhaps we have a lesson to learn.

Similarly, in a suburban school in the South of England, a Year 8 (aged 12-13) class studying Hinduism are presented with the following learning objectives:

By the end of this lesson we will all be able to [...]

(1) Tell a story of Ganesha.

(2) Understand what he represents and why he is worshipped.

(3) Recognize the symbolism in Ganesha icons.

(4) Identify why Hindus pray to Ganesha.

[After telling the story of Ganesha's head, the teacher, Ms G says that Hindus are 'not that bothered' whether the story is literally true].

B: Anything is possible

Ms G: Exactly, it's demonstrating that with God, anything is possible, very insightful.

R: If [Shiva]'s the god of destruction, wouldn't you kind of expect that? [...]

Ms G: Sometimes even with the best intentions [we do or think wrong things,

Shiva is] trying to work with us [...] to try to destroy and get rid of all the nastiness

that's in us. Mrs G asks if students can think of other stories where God gets angry.

L: Noah.

R: Adam and Eve.

Ms G: So we've got God showing anger in other parts of the scriptures as well.

The apparent flattening of the interfaith content - alluded to by the universalising language of 'the scriptures' to encompass both Hindu and Judeo-Christian religious writings - is illustrative of attempts to elide rather than engage with questions of truth, plurality and discernment. In some cases, an approach that fails to adequately differentiate between understanding and reflection leads some students to struggle with more philosophical and open questions. The lack of a clear sense of progression is a known problem in RE (Ofsted 2010: 10), and in a minority of cases metaphysical 
and transcendent questions caused concern and anxiety. One teacher in a Scottish school, for example, remarked:

I have a pupil this year who I think already is going to fail because we've been doing Buddhism and the three universal marks of conditioned existence, she could understand impermanence, that everything was impermanent, but when you got to the no soul, there being no permanent self, she's been completely stressed out. 'I have a soul Mrs S, my soul is going to go to heaven or hell' [...].

In a school in the North of England, a class were writing a reply to a letter from a holocaust survivor in which they are to think about the views of Christians and Buddhists and also give their own opinion. The teacher, $\mathrm{Mr}$ J, has again indicated that students have difficulty explaining or articulating their own views. He aims to address this by beginning with a stimulus called 'Beyond Belief which consists of students placing belief statements on a grid according to whether the group agrees or disagrees with them:

The statements regarding religious beliefs are mostly being placed in the negative squares and there doesn't appear to be much discussion within the groups. Boys on the table nearest me appear not to be taking the task too seriously and this seems to be due to a combination of lack of interest in overtly religious statements and some adolescent embarrassment about the more personal statements such as 'love is the most important thing in life'.

The combination of closed agree/disagree questions, a disconnect from the values of the learners, and an essentialised Other in the form of Buddhist and Christian perspectives typify much of the practice we have characterised as intoleration. What is of particular interest in a post-Deweyan world is the way in which 'learning from each other' goes unproblematised. Of course it may be no more than yet one more instance of phatic communication, but given the embeddedness of this claim in other features of RE, not only in the instances illustrated above but more pervasively in the data, we suggest that the widespread practice of uncritically valorising students' opinions reinforces an acceptance of intoleration as the dominant modus operandi of many RE classrooms.

For example, in an inner-city school in London, students are discussing views on marriage and sexual ethics. One vocal Christian's view diverges from the majority. What is worthy of note is the manner in which this student concludes by rolling back from her earlier stridency in what may be considered a strategy of re-normalising her position within a pervasive liberal framing. While the debate that follows ostensibly opens space for dialogue, the disposition which the teacher praises represents the abandonment of a deeply held conviction on the part of one student:

V: If you're a Christian, you believe in God, you believe what the Bible is saying [...] you should be living by the rules that the Bible has set. [ $\mathrm{V}$ is a powerful and passionate speaker. She attempts to defend the traditional Christian perspective. A generalised 'you' in her speech implies the teacher and other students complicit in opposing her. 
Ms $\mathrm{R}$ (the teacher) challenges, she asks what if a Christian doesn't have the willpower to resist].

$\mathrm{V}$ : Please, this class is driving me crazy, can I just say this one thing [...]

$\mathrm{J}$ : [speaking in support of V] If you're saying it's out of date, then you're saying the Bible's out of date. [There is a heated, high energy atmosphere in the class now. The class becomes chaotic, several girls talking at the same time, heatedly, about the cost of weddings. While one student talks to the class, others talk about her ideas to one another]. You know you said, like, marriage is pointless/

Ms R: No, I said is marriage pointless?

$\mathrm{V}$ : [tries to get the teacher's attention] I've been good, I've only said one thing [although others have also spoken in support of marriage, $\mathrm{V}$ has taken on herself the role of sole defender of a traditional Christian view].

Ms R: [tries to summarise and clarify what others have said, to diffuse the confrontation]: You don't just learn from the slides, from me, you're learning from each other

[Toward the end of the discussion, V says]: I'm not saying that it [premarital sex] is wrong and you're not a proper Christian if you don't.

Ms R: 'Well done' [she praises the way V has taken a view, listened to others, and revised that view to accommodate others. Three or four students applaud].

Given the paucity of time available to many RE teachers, it is clear that a partial explanation for such practices can be found in the ubiquitous practice of eliding difficult questions in the interest of 'covering' content. Intoleration finds few explicit advocates but is often the product of a pragmatic reduction of complex and challenging content in the context of a competing panoply of aims. In a difficult class in an Inner London Catholic school, for example:

[o]ne student asks a question about other faiths and salvation, this creates a discussion which diverts the teacher from the lesson topic. At the end of the class, Mrs R says she 'can't let $10 \mathrm{~g} 1$ talk', she takes a didactic approach because they have a tendency to go off-topic otherwise. Mrs R is fed up of the constant battle for quiet [...] she tells me lessons need to be teacher-led because of behaviour, she doesn't like this but accepts it.

Returning to Copley's definition of indoctrination as education for the inculcation of belief regardless of evidence, indoctrinatory teaching is an attempt to impose meanings, or to impose a lifeworld, rather than enabling and equipping young people with the tools to critically evaluate meaning in their life world. Almost without exception, the only examples which admit of an indoctrinatory reading in the ethnographic data-set relate to teaching for the purpose of nurturing an uncritical tolerance of the Other. These examples constitute attempts to bypass the reason, in-doctrination for the teaching of tolerance, regardless of the evidence: in-toleration. Ignoring of evidence, and the lifeworld, however, frequently leads to a complicit attitude among students, a knowing acceptance that the presentation of Other religions in the classroom, in the examination syllabus, does not cohere with their experiences in lived reality. Not only is this pedagogy of intoleration instrumental, but it is also inefficiently instrumental, failing even by the minimal standards of instrumentalism. 


\section{Discussion and Conclusions}

Through a series of enacted classroom encounters, two conceptions of contribution of $\mathrm{RE}$ to learning about the Other emerge. Their presence is an important aspect of the 'inscape' of RE as experienced by learners (Conroy et al. 2013: 17). Good examples are rare; more frequently, a failure to find coherence with the life world of the student leads to a complicit acceptance of curriculum content for examination purposes. In the first conception, a rare, challenging, but important model of meaning-sharing is in evidence: a pedagogy of encounter wherein students bring contested religious metanarratives into dialogue, without any expectation of resolution or commensurability. Sadly, such examples are rare even within our self-identified purposive sample of good practice.

In the latter conception, intoleration, an attempt is made to bypass discernment and meaning. Essentialised readings of religions abound, where differences are relegated to the levels of the facile or the exotic. Dissenting world views are silenced in group discussion by taking a vote. The meaning of light as a symbol of hope and the profound differences in what is hoped for are elided by the mere presence of the trope, such as in a wall display of a Menorah, a Diwa lamp and a Christmas tree under the banner 'festivals of light'. Such approaches presuppose a conceptual apparatus only suited to understanding the religions of abstracted Others from the outside, and not for their incorporation within a dialogical space.

Pedagogically, the first of our approaches requires what several of our professional collaborators referred to as 'committed openness', an active commitment to a pluralistic encounter. Such an approach was compatible with personal, deeply held beliefs in a theological or philosophical world view but sought to recognise and value the plurality of commitments within and beyond the classroom space. The second approach assumed a pretended neutrality, a 'view from nowhere' approach to religions. The predominance of the latter approach is borne out by the reactions of school students to our forum theatre presentations (Lundie and Conroy 2012). RE as a social practice depends heavily on learning about the Other; if this social practice is to cohere in a society increasingly plagued by questions about shared 'British values' (Adams 2014), it must attend to meaning as experienced by students and not to the nurturing of a pre-evaluated disposition of uncritical tolerance. Simple steps such as introducing students to religious traditions through the words and experiences of believers, rather than through essentialised and de-contextualised generalities, were highlighted in much student feedback and would represent a step in the direction of an authentically intercultural RE.

\section{Acknowledgement}

The data described above were collected as part of the project: 'Does RE Work?' - an analysis of the aims, practices and models of effectiveness in RE in the UK. 


\section{Disclosure statement}

No potential conflict of interest was reported by the author.

\section{Funding}

Principal investigator Professor James Conroy was funded by the AHRC/ESRC Religion and Society Programme (award \#AH/F009135/1) for the project 'Does RE Work? An analysis of the aims, practices and models of effectiveness in Religious Education in the UK'.

\section{Works Cited}

Adams, R., 2014. Governors of new academies and free schools told to abide by 'British values'. The Guardian, 19 June. Available from: http://www.theguardian.com/education/2014/jun/19/ governors-academies-free-schools-british-values-michael-gove [Accessed 24 June 2014].

Alred, G. and Byram, M., 2003. Intercultural experience and education. Clevedon: Multilingual Matters.

Battaglia, D., 1997. Displacing the visual: of Trobriand axe-blades and ambiguity in cultural practice. In: M. Banks and H. Morphy, eds. Rethinking visual anthropology. New Haven: Yale University Press.

Baumfield, V., et al., 2011. The Delphi method: gathering expert perspectives in religious education. British journal of religious education, 34 (3), 5-19.

Behar, R. and Gordon, D.A., 1995. Women writing culture. Berkeley: University of California Press.

Cameron, D., 2014. British values, Gov.UK. Available from: http://www.gov.uk/government/news/ british-values-article-by-david-cameron [Accessed 19 July 2014].

Carspecken, P.F., 2001. Critical ethnographies from Houston: distinctive features and directions. In: P.F. Carspecken and G. Walford, eds. Critical ethnography and education. London: Elsevier Science, 1-26.

Conroy, J., Lundie, D. and Baumfield, V., 2012. Failures of meaning in religious education. Journal of beliefs and values, 33 (3), 307-321.

Conroy, J., et al., 2013. Does religious education work? A multi-dimensional investigation. London: Bloomsbury Academic.

Copley, T., 2005. Indoctrination, education and god: the struggle for the mind. London: SPCK.

Department for Children, Schools and Families, 2010. Religious education in English schools: nonstatutory guidance. Nottingham: DCSF.

Education Reform Act, 1988. London: HMSO.

Emerson-Moering, A., 2007. Another brick in the wall? QCA's non-statutory national framework for religious education and its philosophical underpinnings. Oxford: Farmington Institute for Christian Studies.

Feinberg, W., 2014. Critical pragmatism and the appropriation of ethnography by philosophy of education. Studies in philosophy and education, 33 (1), 1-9.

Felderhof, M., 2007. Religious education, atheism and deception. In: M. Felderhof, P. Thompson and D. Torevell, eds. Inspiring faith in schools: studies in religious education. Hampshire: Ashgate, 87-97.

Gearon, L., 2013. On Holy ground: the theory and practice of religious education. London: Routledge.

Grimmitt, M., 1987. Religious education and human development: the relationship between studying religious and personal social and moral education. Essex: McCrimmons.

Gundara, J.S., 2000. Interculturalism, education and inclusion. Thousand Oaks, CA: SAGE.

Hoffman, P., 1983. The human self and the life and death struggle. Gainesville, FL: University Press of Florida. 
Ipgrave, J., 2011. Trends in religious education with young children in England's multi-faith society. In: F. Schweitzer, A. Edelbrock and A. Biesinger, eds. Interreligiöse und Interkulturelle Bildung in der Kita [Interreligious and Intercultural education in the kindergarten]. Munster: Waxmann, 125-146.

Keaten, J.A. and Soukup, C., 2009. Dialogue and religious otherness: toward a model of pluralistic interfaith dialogue. Journal of international and intercultural communication, 2 (2), 168-187.

Lundie, D., 2010. Research report: 'does RE work?' An analysis of the aims, practices and models of effectiveness of religious education in the UK. British journal of religious education, 33 (2), $163-170$.

Lundie, D., 2012. Religious education in the UK and Ireland: England and Wales. In: L.P. Barnes, ed. Debates in religious education. London: Routledge, 22-33.

Lundie, D., 2014. Anatomy of a moral Panic: Birmingham's 'Trojan Hoax'. Discover society, 15 December.

Lundie, D. and Conroy, J., 2012. Seeing and seeing through: forum theatre approaches to ethnographic evidence. Journal of beliefs and values, 33 (3), 329-342.

Moran, R., 2001. Authority and estrangement. Princeton, NJ: Princeton University Press.

National Society for Promoting Religious Education, n.d. Guidance for Church of England secondary schools on religious education in light of the new secondary curriculum. London: National Society for Promoting Religious Education.

Office for Standards in Education, Children's Services and Skills (Ofsted), 2010. Transforming religious education: religious education in schools 2006-2009. Manchester: Ofsted, UK Government.

Pike, M., 2010. A tale of two schools: comparing and contrasting Jacobus Fruytier Scholengemeenschap in the Netherlands and Bradford Christian School in England. Journal of beliefs and values, 31 (2), 181-190.

Qualifications and Curriculum Authority (QCA), 2004. Religious education: the non-statutory national framework. Norwich: QCA.

Rose, D.W., 1996. Religious education, spirituality and the acceptable face of indoctrination. In: R. Best, ed. Education, spirituality and the whole child. London: Cassell, 173-183.

School Curriculum and Assessment Authority, 1994. Model syllabuses for religious education. London: SCAA.

Schools Council, 1971. Religious education in secondary schools. Lancaster, Schools Council Working Paper 36.

Scottish Office Education Department, 1992. Religious and moral education 5-14. Edinburgh: SOED. Smith, A., 1996. Julia Kristeva: readings of exile and estrangement. Basingstoke: Macmillan.

Strhan, A., 2010. A religious education otherwise? An examination and proposed interruption of current British practice. Journal of philosophy of education, 44 (1), 23-44.

Trondman, M., 2008. Bypass surgery: rerouting theory to ethnographic study. In: G. Walford, ed. How to do educational ethnography. London: Tufnell Press, 115-140.

Turner, V., 1974. Dramas, fields and metaphors: symbolic action in human society. London: Cornell University Press.

Turner, V., 1988. The anthropology of performance. New York: PAJ.

Wright, A., 2000. Spirituality and education. London: Routledge. 